\section{Effect of physical intimate partner violence on body mass index in low-income adult women}

\author{
Efeito da violência física entre parceiros íntimos no \\ índice de massa corporal em mulheres adultas de \\ uma população de baixa renda
}

\author{
Efecto de la violencia física en la pareja y el \\ índice de masa corporal en mujeres adultas \\ pertenecientes a la población con bajos ingresos
}

\begin{abstract}
This study aimed to assess whether physical intimate partner violence affects the nutritional status of adult women with different levels of body mass index (BMI). This was a populationbased cross-sectional study with 625 women selected through complex multistage cluster sampling. Information on physical intimate partner violence was obtained with the Revised Conflict Tactics Scales, and nutritional status was measured as BMI ( $\left.\mathrm{kg} / \mathrm{m}^{2}\right)$. A quantile regression model was used to assess the effect of physical intimate partner violence at all percentiles of BMI distribution. Physical intimate partner violence occurred in 27.6\% of the women (95\%CI: 20.0; 35.2). Mean BMI was $27.9 \mathrm{~kg} / \mathrm{m}^{2}$ (95\%CI: 27.1 ; 28.7). The results showed that physical intimate partner violence was negatively associated with BMI between the 25th and 85th percentiles, corresponding to 22.9 and $31.2 \mathrm{~kg} / \mathrm{m}^{2}$. The findings support previous studies indicating that physical intimate partner violence can reduce BMI in low-income women.
\end{abstract}

Domestic Violence; Violence Against Women; Nutritional Status
Marcela de Freitas Ferreira 1

Claudia Leite de Moraes 1,2

Michael Eduardo Reichenheim 1

Eliseu Verly Junior 1

Emanuele Souza Marques 1

Rosana Salles-Costa ${ }^{3}$

\section{Resumo}

O objetivo do artigo foi avaliar se a violência física entre parceiros intimos interfere no estado nutricional de mulheres adultas com diferentes níveis de indice de massa corporal (IMC). Trata-se de um estudo transversal de base populacional com 625 mulheres selecionadas por uma amostragem complexa por conglomerados em múltiplos estágios. As informações sobre a violência física entre parceiros íntimos foram obtidas por meio do Revised Conflict Tatics Scales. O estado nutricional foi avaliado pelo IMC em $\mathrm{kg} / \mathrm{m}^{2}$. Para avaliar o efeito independente da violência física entre parceiros intimos em diferentes percentis da distribuição do IMC, utilizou-se o modelo de regressão quantílica multivariado. A violência física entre parceiros intimos ocorreu em 27,6\% (IC95\%: 20,0; 35,2\%) das mulheres e a média do IMC foi de $27,9 \mathrm{~kg} / \mathrm{m}^{2}$ (IC95\%: 27,1; 28,7\%). Os resultados indicam que a presença da violência física entre parceiros íntimos associou-se negativamente ao IMC em mulheres com valores entre os percentis 25 e 85 de sua distribuição, que correspondem aos valores 22,9e $31,2 \mathrm{~kg} / \mathrm{m}^{2}$. Os resultados corroboram estudos anteriores que indicam que a violência física entre parceiros íntimos pode reduzir o IMC em mulheres de baixa renda.

Violência Doméstica; Violência Contra a Mulher; Estado Nutricional 


\section{Introduction}

Intimate partner violence is a human rights violation and one of the main forms of interpersonal violence 1. In 2002, the World Health Organization (WHO) defined such violence as "any behavior within an intimate relationship that causes physical, psychological, or sexual harm to those in the relationship and includes acts of physical aggression, psychological abuse, sexual coercion, and various controlling behaviors" 1 (p. 89). Intimate partner violence is a universal phenomenon with a complex web of risk factors and specific consequences for the victim's health. Intimate partner violence has drawn increasing attention from the health sector, occupying a growing place in the public policy agenda and discussion in nongovernmental institutions 1,2,3.

Prevalence of intimate partner violence is high worldwide. According to a multicenter study by the WHO in 15 regions of ten different countries, including Brazil 4, the problem affects 13 to $61 \%$ of women, with estimates varying from 23 to $49 \%$ in most countries. According to authors, 4 to $49 \%$ of women reported having suffered serious physical violence from their current or past partners. In Brazil, 27.2\% of women in the city of São Paulo and $33.7 \%$ in the Zona da Mata in Pernambuco State reported having suffered physical violence some time in life 5 , and that most situations were not isolated acts, but part of a pattern of continuous abuse 4 . The first national population-based survey that studied couples' strategies to resolve everyday conflicts in 16 Brazilian State capitals and the Federal District in 2002-2003 estimated prevalence rates of 21.5 and $12.9 \%$ for minor physical abuse and serious physical abuse in the couple, respectively, in the 12 months prior to the interview ${ }^{6}$. Considering only physical violence perpetrated against women, especially serious physical violence, the problem was more frequent in the North and Northeast regions of Brazil and in low-income families with less schooling 7 .

Intimate partner violence has serious consequences at the individual level, harming the victim's physical and mental health, and the family and social levels 7,8,9,10. Since the early 2000s, studies have investigated a possible association between experiencing situations of family violence and individual nutritional status. The literature has focused especially on violence in childhood or adolescence and its repercussions during this same phase of life or later, in adulthood. Although the findings are still limited, they point to a direct statistical association between violence and overweight/obesity 11,12,13. The main assumption of such studies is that suffer- ing abuse oneself and witnessing intimate partner violence during childhood and adolescence trigger various mental health problems and lead to excessive consumption of high energy-density foods and reduced physical activity, lifestyles that can last into adulthood 13,14.

By extension, and along the same line of reasoning, the experience of intimate partner violence in adulthood might be expected to display this same profile (associated directly with overweight and obesity in women). However, this is not what the literature shows on the relationship between intimate partner violence and nutritional status. Only one of four such studies corroborates the assumption. According to a study of 5,015 Egyptian women in 2011 (Egypt Demographic and Health Survey) 14, only the more severe forms are associated with obesity, namely those involving psychological, physical, and sexual violence. The other studies, on the contrary, either indicate the lack of any relationship or that the experience of intimate partner violence leads to underweight (malnutrition/ thinness). A recent study in the United States with a sample of 1,449 women suggested no significant association between body mass index (BMI) and intimate partner violence, or between the latter and physical activity ${ }^{15}$. Meanwhile, the two studies that showed an association between intimate partner violence and underweight were conducted in India. The first focused on women $(n=747)$ in poor rural and tribal communities in southern India, showing an association between underweight and psychological abuse and sexual coercion 16 . The other, based on the Indian $\mathrm{Na}$ tional Family Health Survey and including 69,072 women, showed an association between malnutrition and physical intimate partner violence 17 .

The literature on the impact of intimate partner violence on women's nutritional status is thus still limited, and above all ambivalent. The dramatic change in the world population's nutritional profiles in recent decades $18,19,20$ has triggered a plethora of scientific studies, which is obviously justifiable. Still, research on the possible determinants of this transformation has proven insufficient in relation to the paths leading to excess weight. One of the gaps is the effect of certain psychosocial aspects on this process, among which intimate partner violence. As discussed, the studies apparently point in opposite directions, thus requiring new evidence and analyses. Likewise, the huge magnitude of intimate partner violence worldwide (and not least in Brazil) requires in-depth examination of its consequences, particularly its repercussions on nutritional status. The main objective of the current study was thus to assess the effect of physical 
intimate partner violence on BMI in adult women, focusing especially on a low-income population, with presumably high rates of excess weight and intimate partner violence.

\section{Methods}

\section{Study design and population}

This was a cross-sectional population-based study in Duque de Caxias, Greater Metropolitan Rio de Janeiro, Brazil. Participants were selected through multiple-stage cluster sampling (census districts, permanent private households, and individuals), using inverse sampling as the field strategy 21 . For this particular study, the eligibility criteria were women 20 to 59 years of age living in the Campos Elíseos District in the Municipality of Duque de Caxias who were not pregnant or breastfeeding and that reported being in some intimate partner relationship during the 12 months prior to the interview. Among the 1,035 interviewees in the background study, 644 met the inclusion criteria. Of these, 625 women were actually analyzed, since 19 (2.9\%) refused to have their anthropometric measures taken.

\section{Data collection}

The field work took place from April to December 2010. Data were collected through face-to-face interviews with the reference woman in each household. All interviews were held in a reserved place in the household, without the male partner's presence. The questionnaire modules on intimate issues were only applied by female interviewers, as recommended by the WHO 22 .

Anthropometric measures were taken by trained, specifically qualified personnel. The women were requested to wear only light clothing and no footwear. Height was measured twice with a WCS stadiometer (capacity $220 \mathrm{~cm}$. Cardiomed Comércio de Equipamentos Médicos Ltda., Curitiba, Brazil) placed on a flat, smooth, solid surface. The mean of the two measurements was used. Weight was measured with a G-Tech digital scale (Accumed Glicomed, Niterói, Brazil), with a capacity of $150 \mathrm{~kg}$ and accuracy of $100 \mathrm{~g}$. Women were weighed with their feet positioned in the center of the scale in erect position, with their arms by their sides.

\section{Theoretical-conceptual model and operationalization of variables}

Based on the literature review, a theoretical-conceptual model was elaborated (Figure 1), consist- ing of several dimensions that have frequently been included in studies on the consequences of intimate partner violence for the woman's health, as well as dimensions related to adult women's nutritional status.

As shown in Figure 1, the model's more distal levels include socioeconomic, demographic, and reproductive characteristics, represented by per capita family income measured by multiples of the prevailing minimum wage in the study year, schooling, age, skin color, and number of children. The intermediate level is represented by the dimensions "partner's alcohol use", "woman's perceived degree of social support", and "physical intimate partner violence", the study's central target exposure. Partner's alcohol use was assessed with the Portuguese-language version of the CAGE instrument [(C) Cut-down; (A) Annoyed; (G) Guilty; (E) Eye-opener] 23,24 due to its good accuracy and ease of understanding and application. Suspected alcohol abuse by the partner was defined as a positive response to two or more items, as reported by the woman. Social support was measured by the woman's score on the affective dimension of the social support questionnaire used in the Medical Outcomes Study (MOS) 25,26. This subscale includes three items asking whether the respondent reports having persons that physically display feelings of love and affection for her. Each of the items has five response categories (never, rarely, sometimes, almost always, always), forming a score of 3 to 15.

Information on physical intimate partner violence was obtained from the Portugueselanguage version of the Revised Conflict Tactics Scale (CTS2), adapted for use in Brazil 27,28. The time window for the study was the 12-month period prior to the interview. Physical intimate partner violence was defined as at least one positive item among the 12 dichotomous items on the scale, regardless of having been perpetrated by the woman or her partner. Nutritional status was classified by BMI, expressed as $\mathrm{kg} / \mathrm{m}^{2}$ and based on the WHO classification 29 and the Brazilian Food and Nutritional Surveillance System (SISVAN) 30 .

The theoretical model also postulates that the role of physical intimate partner violence in the woman's BMI is mediated by common mental disorders (CMD), which in turn could alter the woman's alcohol and food consumption, proximal variables vis-à-vis the outcome. As intervening variables, they were not considered in the data analysis models. The other variables are self-explanatory and are presented in the Results. 


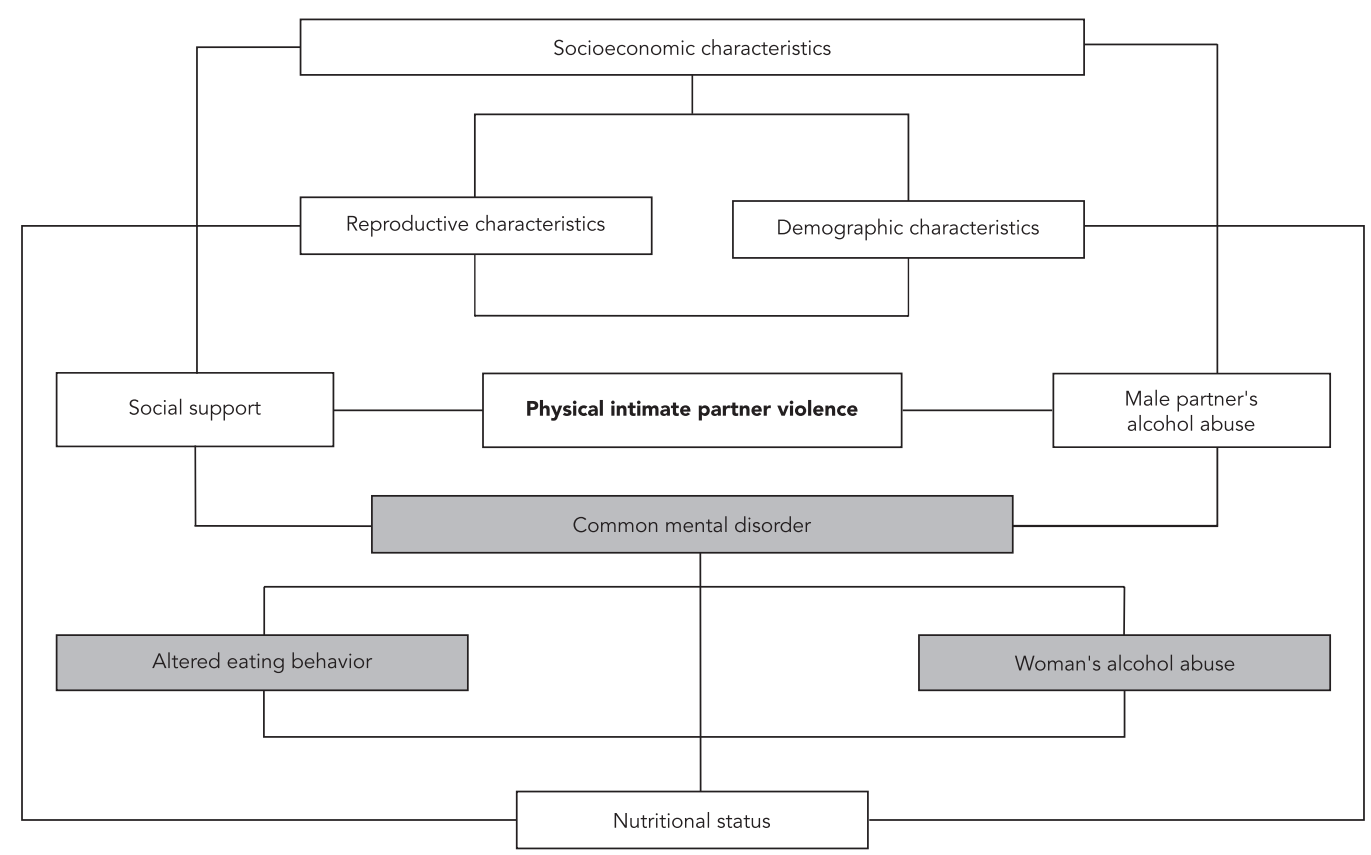

\section{Data analysis}

Data analysis followed the theoretical-conceptual model in Figure 1. The first stage explored the variables' integrity and distribution. We then estimated the quantile regression coefficients from the $5^{\text {th }}$ to the $9^{\text {th }}$ percentile $(5,10,15, \ldots, 90,95)$ to test the association between BMI and each candidate variable for the multivariate model. This regression model is useful for observing the effect of independent variables at different distribution points for the dependent variable and is appropriate when asymmetrical and heteroscedastic in relation to the model's other variables 31 .

Next, using the stepwise-forward procedure, each variable was added to the multivariate model. Following the order proposed by the theoretical-conceptual model, the procedure began with the physical dimensions. Variables were only maintained when they presented statistically significant coefficients in most of the quantiles $(\mathrm{p}<$ 0.05). Standard errors for the quantile regression coefficients were estimated via bootstrap (200 replications) 32 .

Data processing and exploratory analyses used Stata 12.0 (Stata Corp., College Station,
USA). The quantile regression models used SAS version 9.3 (SAS Inst., Cary, USA).

\section{Ethical issues}

The study was approved by the Ethics Research Committee of the Institute for Studies in Public Health (IESC), Federal University of Rio de Janeiro (case review no. 73/2009, May 18, 2009). At the home interview, participants signed a free and informed consent form after an explanation of the study procedures, guarantee of anonymity, and possibility of refusal to participate in the study.

\section{Results}

Women's mean BMI was 27.9kg/m² (95\%CI: 27.0; 28.7). Prevalence rates were: underweight $1.2 \%$ (95\%CI: $0.1 ; 2.2)$, normal weight $31.8 \%$ (95\%CI: 24.6 ; 38.9), overweight $36.9 \%$ (95\%CI: 31.1; 42.7), and obesity $30.1 \%$ (95\%CI: $23.5 ; 35.7)$. Slightly more than one-fourth of the women $[27.6 \%$ (95\%CI: 20.0; 35.2)] reported at least one episode of physical aggression involving the intimate 
partner in the previous 12 months, either as perpetrator or victim.

Table 1 shows the study population's sociodemographic and reproductive profile. A high proportion of women had per capita monthly family income less than one minimum wage (84.6\%) and had not finished secondary school (72.1\%). Women's mean age was 38.6 years, mean number of children was 2.1 , and $25.7 \%$ defined themselves as heads of the family. Slightly more than one-third of the women identified themselves as white. Nearly $90 \%$ were married or in stable unions. According to the women, some $10 \%$ of male partners were identified as suspected of alcohol abuse.

Table 1 also shows BMI at the different distribution percentiles according to the study population's characteristics. At most percentiles, BMI was higher among women who had not suffered physical intimate partner violence, those with less schooling, those with lower income (except those that reported not having any income), nonwhites, those married or living in a stable union, with more children, and having a partner identified as suspected of alcohol abuse.

The final quantile regression model included eight explanatory variables, namely physical intimate partner violence, schooling, skin color, number of children, woman's age, per capita family income in multiples of the minimum wage, partner's alcohol abuse, and perceived degree of social support (affective dimension). Figure 2 shows the trend in the regression coefficients for physical intimate partner violence along the distribution of the woman's BMI. These coefficients express the difference in BMI between the categories of physical intimate partner violence (BMI in exposed versus unexposed). The gray band in Figure 1 shows the 95\% confidence intervals $(95 \% \mathrm{CI})$ for the estimated coefficient in each percentile. As shown, all the coefficients were negative, and the pattern becomes sharper as the BMI percentile increases. However, the estimated values were only statistically significant between the $25^{\text {th }}$ and $85^{\text {th }}$ percentiles, corresponding to BMI of $22.9 \mathrm{~kg} / \mathrm{m}^{2}$ and $31.2 \mathrm{~kg} / \mathrm{m}^{2}$. The graph as a whole indicates that exposure to physical intimate partner violence reduces BMI and that this reduction becomes progressively sharper, although only among women in a certain BMI range.

Figure 3 shows another view of the independent effects of physical intimate partner violence at different BMI levels, showing the quantile differences in mean BMI between women unexposed and exposed to physical intimate partner violence (light and dark dots, respectively). Means for unexposed women were calculated directly from the data. BMI values for exposed women are projections obtained from these means, subtracting the respective estimated coefficients in the final quantile regression model (Figure 2). Congruently, the differences between mean BMI in exposed and unexposed women increase with increasing BMI. In some quantiles, these differences mean that exposed and unexposed women are classified in distinct BMI categories, indicated by the dotted horizontal lines separating (from bottom to top) the areas for underweight, normal weight, overweight, and obesity. Considering only the BMI range in which the effect of physical intimate partner violence was statistically significant (from the $25^{\text {th }}$ to $85^{\text {th }}$ percentile), reclassification occurs in five of the 13 quantiles, projecting that $30 \%$ of all the women are potentially involved in this situation (five of twenty quantiles).

\section{Discussion}

Prevalence of physical intimate partner violence in the previous 12 months (27.6\%) exceeded the estimated rates from the first national survey in 2002-2003, both for the 16 cities participating in the study $(20.8 \%)$ and specifically the city of Rio de Janeiro (22.6\%) 6 . The current estimate is similar to those found in underprivileged regions of Brazil like the North and Northeast (29.8\%) 6 . Prevalence was also higher than in the 1 st National Surveyon Alcohol Consumption in Brazil (20052006), which included 1,445 married adults (or those living in stable unions), namely $14.6 \% 33$. The higher prevalence found in the current study may result from socioeconomic characteristics of the study population, which includes a large proportion of women with per capita monthly income less than one minimum wage $(84.6 \%)$, non-white women (68\%), and those who had not finished secondary school $(72.1 \%)$. As a whole, this suggests that physical intimate partner violence is also a socially determined health-disease process, a view supported by other Brazilian and international studies 1,7,34. Thus, policies and programs to promote peace and deal with situations of violence (especially gender-related) should also tackle not only gender discrimination but also discrimination on grounds of color/ race and social class, since they are usually interrelated and superimposed 35,36 . They should thus include macrostructural actions that promote development and reduce social inequalities. In order to interrupt the process of intimate partner violence and safeguard women's well-being, the health sector should implement measures for early detection of existing cases and deal with 
Table 1

Percentiles of body mass index $\left(\mathrm{BMI}=\mathrm{kg} / \mathrm{m}^{2}\right)$ according to exposure to physical intimate partner violence, socioeconomic, demographic, and reproductive characteristics, and male partner's alcohol abuse $(N=581)$. Duque de Caxias, Rio de Janeiro State, Brazil, 2010.

\begin{tabular}{|c|c|c|c|c|c|c|c|c|c|}
\hline Variable & $\mathrm{n}$ & $\%$ & p5 & $\mathrm{p} 10$ & p25 & p50 & p75 & p90 & p95 \\
\hline \multicolumn{10}{|l|}{ Physical intimate partner violence } \\
\hline Yes & 168 & 27.61 & 20.07 & 21.26 & 22.92 & 25.32 & 29.17 & 32.83 & 38.16 \\
\hline No & 413 & 72.38 & 20.32 & 21.79 & 24.60 & 27.68 & 31.05 & 36.34 & 40.98 \\
\hline \multicolumn{10}{|l|}{ Woman's schooling } \\
\hline Complete secondary schooling or more & 183 & 27.92 & 20.03 & 21.26 & 23.25 & 25.84 & 29.79 & 35.59 & 38.65 \\
\hline 9th year primary to 2 nd year secondary school & 211 & 41.17 & 20.24 & 22.04 & 24.22 & 27.55 & 30.91 & 36.34 & 40.15 \\
\hline 8th year of primary or less & 187 & 30.89 & 20.32 & 22.31 & 24.43 & 28.13 & 30.66 & 35.00 & 38.13 \\
\hline \multicolumn{10}{|c|}{ 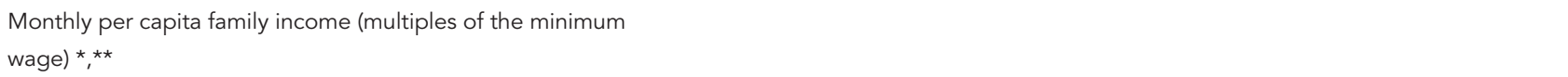 } \\
\hline$\geq 1$ & 86 & 15.36 & 20.67 & 21.79 & 23.34 & 26.45 & 29.80 & 31.41 & 32.80 \\
\hline $1 / 2 \mid-1$ & 220 & 41.18 & 20.31 & 21.97 & 24.33 & 26.63 & 30.41 & 34.61 & 38.13 \\
\hline $1 / 4 \mid-1 / 2$ & 187 & 30.61 & 21.02 & 21.64 & 24.22 & 28.13 & 31.85 & 39.29 & 42.62 \\
\hline$<1 / 4$ & 86 & 12.38 & 19.10 & 20.90 & 24.44 & 27.22 & 30.45 & 34.73 & 37.46 \\
\hline No income & 2 & 0.46 & 22.25 & 22.25 & 22.25 & 22.25 & 22.25 & 22.25 & 29.60 \\
\hline \multicolumn{10}{|l|}{ Woman's position in the family } \\
\hline Head of family & 160 & 25.74 & 21.26 & 22.34 & 24.54 & 27.36 & 31.05 & 34.72 & 36.58 \\
\hline Not head of family & 421 & 74.25 & 20.03 & 21.23 & 23.58 & 27.06 & 30.46 & 36.34 & 40.99 \\
\hline \multicolumn{10}{|l|}{ Age (years) ** } \\
\hline $20 \mid-30$ & 139 & 20.38 & 19.10 & 19.80 & 22.50 & 26.81 & 31.20 & 38.65 & 42.62 \\
\hline $30 \mid-40$ & 174 & 39.27 & 21.03 & 21.89 & 23.73 & 25.94 & 30.12 & 33.39 & 38.37 \\
\hline $40 \mid-50$ & 170 & 23.24 & 20.86 & 22.99 & 24.77 & 27.63 & 30.59 & 35.59 & 40.15 \\
\hline $50 \mid-60$ & 98 & 17.10 & 20.32 & 21.36 & 24.88 & 27.70 & 31.41 & 36.05 & 36.58 \\
\hline \multicolumn{10}{|l|}{ Color } \\
\hline Black, brown, yellow, indigenous & 395 & 65.65 & 20.31 & 22.34 & 24.74 & 27.67 & 31.08 & 36.37 & 39.29 \\
\hline White & 186 & 35.35 & 20.02 & 20.85 & 22.88 & 25.82 & 29.36 & 33.01 & 40.08 \\
\hline \multicolumn{10}{|l|}{ Marital status } \\
\hline Single & 36 & 6.25 & 17.67 & 19.78 & 22.39 & 25.90 & 30.93 & 36.58 & 36.76 \\
\hline Married/Common-law union & 519 & 88.70 & 20.32 & 21.89 & 23.80 & 27.03 & 30.90 & 36.05 & 40.16 \\
\hline Separated/Divorced & 25 & 5.05 & 19.90 & 23.98 & 25.78 & 25.52 & 30.12 & 32.51 & 34.57 \\
\hline \multicolumn{10}{|l|}{ Number of children } \\
\hline None & 51 & 10.78 & 19.53 & 20.03 & 22.39 & 25.24 & 29.16 & 38.13 & 43.81 \\
\hline 1 & 175 & 31.70 & 19.50 & 21.09 & 23.40 & 26.37 & 30.12 & 34.61 & 38.65 \\
\hline 2 & 183 & 32.60 & 20.90 & 22.34 & 24.33 & 27.21 & 30.58 & 36.37 & 41.65 \\
\hline 3 or 4 & 142 & 21.53 & 22.31 & 23.34 & 25.15 & 28.30 & 30.93 & 35.45 & 37.42 \\
\hline$\geq 4$ & 30 & 3.43 & 19.10 & 20.93 & 26.10 & 29.14 & 33.33 & 35.56 & 37.41 \\
\hline \multicolumn{10}{|l|}{ Partner's alcohol abuse } \\
\hline Yes & 61 & 10.44 & 22.32 & 22.92 & 25.15 & 30.12 & 33.33 & 36.34 & 40.99 \\
\hline No & 520 & 89.56 & 20.03 & 21.44 & 23.73 & 26.90 & 30.45 & 35.00 & 39.23 \\
\hline
\end{tabular}

* Monthly per capita family income (total family income divided by number of household residents, expressed as multiples of the minimum wage of R $\$ 581.81$, prevailing in Rio de Janeiro State in 2010);

** Evaluated as continuous variables in the multivariate quantile regression model. 
Figure 2

Multivariate quantile regression coefficients according to body mass index (BMI).

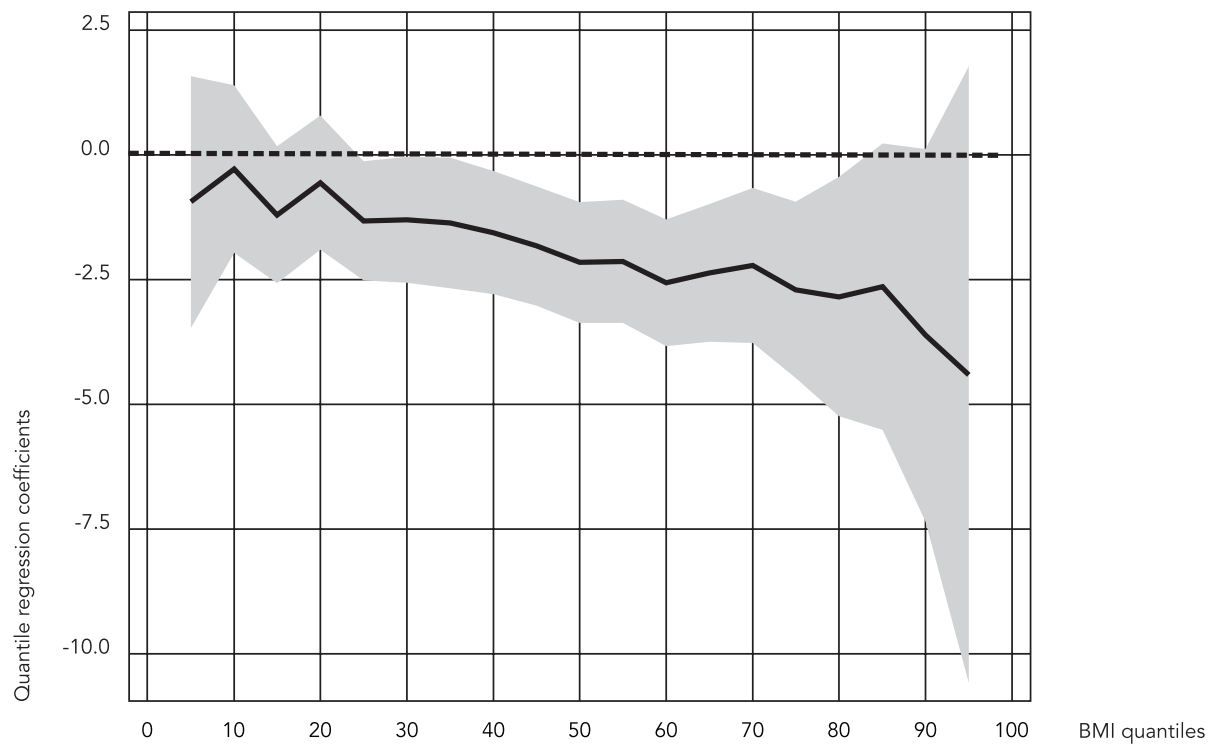

Figure 3

Mean body mass index (BMI) in women exposed and unexposed to physical intimate partner violence according to BMI quantiles.

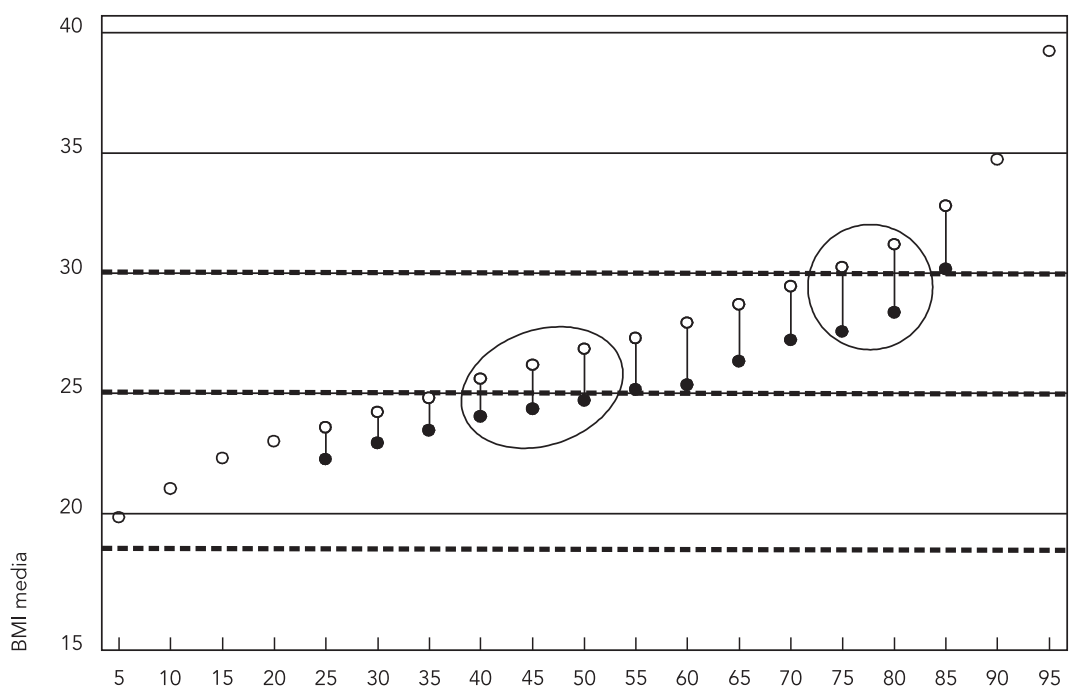

O Physical intimate partner violence -

- Physical intimate partner violence + 
them appropriately through linkage within the health system and with other support networks.

The high prevalence rates for overweight (36.9\%) and obesity (30.1\%) jointly affect more than two-thirds of the women interviewed in the study and also require attention. Both exceed the prevalence rates $(34.9 \%$ and $22.4 \%$ ) found in the 2005 survey in the same population 37 . In only half a decade, excess weight increased by approximately $17 \%$, and obesity by $34 \%$. This alarming trend in the study population is consistent with that found in the Brazilian adult female population. In perspective, from the national survey conducted in 1974 (National Family Spending Survey) to that in 2009 (Family Budgets Survey POF), the prevalence of excess weight increased by $67 \%$ in Brazilian women. According to the last Family Budgets Survey, in the late 2000s, excess weight already affected nearly half of all Brazilian women $(48 \%)$. The fact that the current sample included a large percentage of low-income women with low schooling, known to be more vulnerable to the dynamics of excess weight 38,39 , meant that our estimates greatly exceeded the figures for Brazil as a whole.

The increased risk of excess weight and intimate partner violence in low-income populations, as well as the repercussions of intimate partner violence on women's mental health, suggest that experiencing intimate partner violence over the course of life might be a risk factor for overweight and obesity. However, that is not what our data indicate. As seen above, our data showed an important negative association between physical intimate partner violence and BMI. This finding corroborates at least two of the four studies that addressed the theme 16,17, besides suggesting a different picture from that found in studies focusing on the repercussions of witnessing intimate violence in childhood and violence against children and adolescents, by refuting the alternative hypothesis that physical intimate partner violence is a risk factor for weight gain.

Admittedly, there are two other studies focusing on the impact of intimate partner violence on women's nutritional status that do not subscribe to this negative association, either because they fail to show evidence of any relationship when considering violence of any nature 14,15 or because they even show a positive convergence in extreme situations 14. The lack of consensus in the literature may result from the fact that the current study and those by Sethuraman et al. 16 and Ackerson \& Subramanian 17 , conducted in India, specifically and exclusively assessed intimate partner violence of the physical type, while the other two studies focused on intimate partner violence in its different manifestations. Although they also used CTS2 27 to characterize violence in the study on Egyptian women, Yount \& Li 14 explored psychological, physical, and sexual violence jointly, thus hindering a more accurate conclusion on the specific effect of physical violence. The same occurred in a study in the United States by Mathew et al. 15 that not only used a simplified instrument to characterize situations of violence, but also assessed violence jointly and nonspecifically. Another explanation for the conflicting results would be that the relations between intimate partner violence and the woman's nutritional status depend on the study population's socioeconomic context. The current study and those by Sethuraman et al. 16 and Ackerson \& Subramanian 17, in India, were conducted in low-income and low-schooling populations, unlike the studies in Egypt and the United States, which worked mainly with middle-income populations.

The negative relationship between physical intimate partner violence and BMI raises some issues on the processes potentially involved in such behavior. According to Ackerson \& Subramanian 17 , the negative association between physical intimate partner violence and BMI results from the physically violent partner's intent to withhold food as a form of psychological abuse, ultimately preventing the woman from maintaining normal nutritional status. One can also conjecture that chronic daily stress for a poor woman suffering violence would lead to sleep disorders, alcohol and drug abuse, smoking, and reduced food intake $1,14,40$. In fact, this hypothesis is reinforced by evidence that stress increases the baseline metabolic rate and energy expenditure $41,42,43$, a process that can cause weight loss in individuals with adequate or low calorie intake 17 . It would also be worthwhile to consider the debate raised by Seematter et al. 42 and Kivimaki et al. ${ }^{44}$, suggesting that the impact of stress on weight can vary according to the individual's lifetime nutritional status. The authors propose that individuals with baseline excess weight/obesity would further increase their body weight when exposed to stressful situations. Meanwhile, normal-weight or underweight individuals would tend to lose weight under stress. This hypothesis is inconsistent with our findings, since in all BMI brackets (except in the extremes), physical intimate partner violence appeared to reduce BMI. At any rate, the hypothesis merits future testing in studies that measure the woman's nutritional status prior to exposure to physical intimate partner violence (and to the stress that the latter presumably triggers). 
Importantly, a superficial assessment considering only the woman's BMI classification might suggest that intimate partner violence has a beneficial effect on her overall health, purportedly exerting a "protective" effect against overweight and obesity. Thus, from the strictly nutritional point of view, "potentially" overweight or obese women would remain closer to the recommended BMI ranges. Still, one can hardly imagine that female victims of violence would enjoy a varied, balanced, and healthy diet, accompanied by regular physical activity to keep them in a reasonable body weight range, reflected in their BMI values. What may be happening is that the chronic stress experienced by these women prevents them from gaining weight, even when subject to a poorly balanced, potentially high-calorie, and low-quality food supply.

Considering such subtleties, an approach restricted to nutritional status clearly fails to identify situations of chronic stress, the repercussions of which are increasingly recognized as underlying characteristics of chronic diseases in later phases of life, such as cardiovascular and metabolic conditions, among others. Since the findings show that at least one-fourth of the women live with this situation (physical intimate partner violence was present in $27.6 \%$ of the households), we strongly recommend that health interventions targeting women, whether "nutritional" (food policies) or not, be integrated and comprehensive, providing room for health services to identify and deal with these and other dramas.

The evidence that the negative effect of physical intimate partner violence on BMI only occurs in women within a certain range of nutritional status - namely with BMI from $23 \mathrm{~kg} / \mathrm{m}^{2}$ to $31 \mathrm{~kg}$ / $\mathrm{m}^{2}$, as the data here suggest - also raises some questions. Could this specificity at least partially explain the conflicting findings in previous studies? Would this profile also be found by focusing on populations from social strata with higher purchasing power, including women with greater financial autonomy and access to healthier foods? And would such relations be maintained when considering other forms of interpersonal violence and other psychosocial events such as depression and social isolation? Such questions will also require studies that involve populations from other socioeconomic strata and that simultaneously evaluate these and other psychosocial factors, using statistical models that allow studying the effects at different BMI levels, as in the case of quantile regression.

The results of the current study should be interpreted in light of its strengths and limitations. Among the positive aspects, this was the first Brazilian study to address the relationship between intimate partner violence and women's nutritional status, and it is highly relevant for studies on the repercussions of intimate partner violence and for research programs that explore the determinants of adult women's nutrition. Another positive aspect was the use of an epidemiological instrument that is widely used and validated in different contexts in Brazil to detect the occurrence of physical intimate partner violence, decreasing the problem's underestimation and possible misclassification biases $27,28,45$. Another interesting point was the use of quantile regression models 46 , allowing the identification of important nuances in the relationship between physical intimate partner violence and BMI. Importantly, the negative association between the two phenomena already appeared in the data using a traditional linear regression model. Still, the model implemented here allowed exploring and effectively corroborating heterogeneity in the distribution of the effect of exposure to physical intimate partner violence at the outcome's different levels. Interestingly, other Brazilian studies using this methodology have also shown that the relationship between nutritional status and certain events or practices also varies in magnitude, according to levels in nutritional status itself 47,48 .

A potential limitation to the study was the temporal strategy in capturing target information. Since this was a crosscutting approach in which the data collection procedure prevented demarcating the moment at which physical intimate partner violence occurred, or investigating the woman's prior nutritional status, it would be difficult to assume that the exposure actually preceded the outcome. However, considering the chronic nature of intimate partner violence over the course of life 1,49 , it is possible to assume that the recall period used in the study (12 months) allows an acceptable approximation of a more perennial situation, thus providing sufficient time for its nutritional consequences to occur. In addition, an inverse relationship between the woman's nutritional status and physical intimate partner violence does not appear reasonable. On the one hand, it is hard to believe that violent acts are the consequence of the nutritional characteristics of the parties involved. On the other, there is robust evidence that the roots of intimate partner violence lie elsewhere, more in the partners' psychological, sociocultural, and economic spheres $1,7,50,51$.

Another limitation was the lack of information on violence experienced in childhood or adolescence. Studies indicate that children and adolescents suffering family violence (whether directly - especially considering sexual abuse - or indirectly) are more likely to become involved in 
violent intimate partnerships in adulthood, and that the violence in these phases of life can be risk factors for excess weight. Thus, it would have been interesting if our analyses had also considered the history of violence suffered in childhood and adolescence. Unfortunately, background operational issues in the study prevented access to this information. We thus suggest that future studies also address such issues.

In short, the study's findings indicate that both intimate partner violence and excess weight are important public health problems in low-income populations and should be dealt with expeditiously. The data analyzed here also refute the hypothesis that physical intimate partner violence is a risk factor for excess weight in women. The results indicate exactly the opposite, namely that women exposed to physical intimate partner violence tend to display lower BMI when compared to those not exposed to such violence. However, it is essential to investigate these associations in other contexts and domains, encompassing other aspects involved in the process, including different assessments of nutritional status over the course of life, other forms of intimate partner violence, and food consumption profiles. Qualitative studies that delve further into these issues are also welcome, including the women's own perceptions as victims of violence, or of overweight and/or obesity. Expanding the number of studies on the theme will definitely help improve understanding of the process as a whole. Such in-depth research is necessary for the incorporation of psychosocial factors into the formulation of strategic policies and actions focused on the prevention of overweight and obesity, as well as for dealing with situations of intimate partner violence.

\section{Resumen}

El objetivo de este trabajo es evaluar si la experiencia de violencia física entre parejas sentimentales interfiere en el estado nutricional de las mujeres adultas con diferentes niveles de indice de masa corporal (IMC). Se trata de un estudio transversal de base poblacional con 625 mujeres, seleccionadas a través de una muestra compleja por conglomerados. La información sobre violencia física entre parejas sentimentales se obtuvo a través de la Revised Conflicts Tactics Scales. El estado nutricional se evaluó mediante el IMC en $\mathrm{kg} / \mathrm{m}^{2}$. Para evaluar el efecto independiente de la violencia física entre parejas sentimentales en diferentes percentiles de la distribución del índice de masa corporal se utilizó el modelo multivariado de regresión cuantil. La violencia física entre parejas sentimentales se produjo en un 27,6\% (IC95\%: 20,0; 35,2) de las mujeres y el IMC promedio fue 27,9kg/m² [IC95\%: 27,1; 28,7]. Los resultados indican que la presencia de violencia física entre parejas sentimentales se asoció negativamente con el IMC entre las mujeres con un IMC entre 25 y 85 percentiles de la distribución del IMC, que corresponden a los valores de 22,9 y $31,2 \mathrm{~kg} / \mathrm{m}^{2}$.

Violencia Doméstica; Violencia Contra la Mujer; Estado Nutricional

\section{Contributors}

M. F. Ferreira participated in the literature search, data analysis and interpretation, and writing of the text C. L. Moraes collaborated in the study planning and execution, data analysis and interpretation, and writing of the text. M. E. Reichenheim contributed to the study planning and execution and critical revision of the text. E. Verly Junior collaborated in the data analysis and writing of the article. R. Salles-Costa participated in the study planning and execution and critical revision of the text.

\section{Acknowledgments}

The authors wish to thank CNPq and FAPERJ for the research funding. 


\section{References}

1. Krug EG, Dahlberg LL, Mercy JA, Zwi AB, Lozano R. World report on violence and health. Geneva: World Health Organization; 2002.

2. Secretaria de Políticas de Saúde, Ministério da Saúde. Dimensionando a violência na família In: Secretaria de Políticas de Saúde, Ministério da Saúde, organizador. Violência intrafamiliar: orientações para prática em serviço. Brasília: Ministério da Saúde; 2001. p. 7-11. (Série Cadernos de Atenção Básica, 8). (Série A. Normas e Manuais Técnicos, 131).

3. World Health Organization. Intimate partner violence: understanding and addressing violence against women. http://apps.who.int/iris/bitstream /10665/77432/1/WHO_RHR_12.36_eng.pdf (accessed on 28/Jan/2013).

4. World Health Organization. WHO Multi-country Study on Women's Health and Domestic Violence against Women: initial results on prevalence, health outcomes and women's responses. Geneva: World Health Organization; 2005.

5. Schraiber LB, D’Oliveira AF, Franca-Junior I, Diniz S, Portella AP, Ludermir AB, et al. Prevalência da violência contra a mulher por parceiro íntimo em regiões do Brasil. Rev Saúde Pública 2007; 41:797-807.

6. Reichenheim ME, Moraes CL, Szklo A, Hasselmann MH, Souza ER, Lozana JA, et al. The magnitude of intimate partner violence in Brazil: portraits from 15 capital cities and the Federal District. Cad Saúde Pública 2006; 22:425-37.

7. Reichenheim ME, Souza ER, Moraes CL, MelloJorge MH, Silva CM, Minayo MCS. Violence and injuries in Brazil: the effect, progress made, and challenges ahead. Lancet 2011; 377:1962-75.

8. Moraes CL, Arana FD, Reichenheim ME. Physical intimate partner violence during gestation as a risk factor for low quality of prenatal care. Rev Saúde Pública 2010; 44:667-76.

9. Moraes CL, Oliveira AS, Reichenheim ME, Lobato G. Severe physical violence between intimate partners during pregnancy: a risk factor for early cessation of exclusive breast-feeding. Public Health Nutr 2011; 14:2148-55.

10. Ford-Gilboe M, Merritt-Gray M, Varcoe C, Wuest J. A theory-based primary health care intervention for women who have left abusive partners. ANS Adv Nurs Sci 2011; 34:198-214

11. Williamson DF, Thompson TJ, Anda RF, Dietz WH Felitti V. Body weight and obesity in adults and self-reported abuse in childhood. Int J Obes Relat Metab Disord 2002; 26:1075-82.

12. Whitaker RC, Phillips SM, Orzol SM, Burdette HL. The association between maltreatment and obesity among preschool children. Child Abuse Negl 2007; 31:1187-99

13. Midei AJ, Matthews KA. Interpersonal violence in childhood as a risk factor for obesity: a systematic review of the literature and proposed pathways. Obes Rev 2011; 12:e159-72.

14. Yount KM, Li L. Domestic violence and obesity in Egyptian women. J Biosoc Sci 2011; 43:85-99
15. Mathew AE, Marsh B, Smith LS, Houry D. Association between intimate partner violence and health behaviors of female Emergency Department patients. West J Emerg Med 2012; 13:278-82.

16. Sethuraman K, Lansdown R, Sullivan K. Women's empowerment and domestic violence: the role of sociocultural determinants in maternal and child undernutrition in tribal and rural communities in South India. Food Nutr Bull 2006; 27:128-43.

17. Ackerson LK, Subramanian SV. Domestic violence and chronic malnutrition among women and children in India. Am J Epidemiol 2008; 167:1188-96.

18. World Health Organization. Obesity and overweight. http://www.who.int/mediacentre/fact sheets/fs311/en/ (accessed on 14/Nov/2011).

19. Instituto Brasileiro de Geografia e Estatística. Pesquisa de Orçamentos Familiares, 2008-2009: antropometria e estado nutricional de crianças, adolescentes e adultos no Brasil. Rio de Janeiro: Instituto Brasileiro de Geografia e Estatística; 2010.

20. Willett WC, Dietz WH, Colditz GA. Guidelines for healthy weight. N Engl J Med 1999; 341:427-34.

21. Haldane JB. On a method of estimating frequencies. Biometrika 1945; 33:222-5.

22. World Health Organization. Putting women first: ethical and safety recommendations for research on domestic violence against women. Geneva: World Health Organization; 2001.

23. Mayfield D, McLeod G, Hall P. The CAGE questionnaire: validation of a new alcoholism screening instrument. Am J Psychiatry 1974; 131:1121-3.

24. Masur J, Monteiro MG. Validation of the "CAGE" alcoholism screening test in a Brazilian psychiatric inpatient hospital setting. Braz J Med Biol Res $1983 ; 16: 215-8$

25. Sherbourne CD, Stewart AL. The MOS social support survey. Soc Sci Med 1991; 32:705-14.

26. Chor D, Griep RH, Lopes CS, Faerstein E. Medidas de rede e apoio social no Estudo Pró-Saúde: pré-testes e estudo piloto. Cad Saúde Pública 2001; 17:887-96

27. Straus MA, Hamby SL, Boney-McCoy S, Sugarman DB. The Revised Conflict Tactics Scales (CTS2). J Fam Issues 1996; 17:283-316.

28. Moraes CL, Reichenheim ME. Cross-cultural measurement equivalence of the Revised Conflict Tactics Scales (CTS2) Portuguese version used to identify violence within couples. Cad Saúde Pública 2002; 18:783-96.

29. World Heath Organization. Obesity: preventing and managing the global epidemic. Report of a WHO Consulation on Obesity. Geneva: World Heath Organization; 2000.

30. Departamento de Atenção Básica, Secretaria de Atenção à Saúde, Ministério da Saúde. Protocolos do Sistema de Vigilância Alimentar e Nutricional SISVAN na assistência à saúde. Brasília: Ministério da Saúde; 2008.

31. Buchinsky M. Recent advances in quantile regression models: a practical guideline for empirical research. J Hum Resour 1998; 33:88-126. 
32. Efron B, Tibshirani R. An introduction to the bootstrap. London: Chapman and Hall; 1993.

33. Zaleski M, Pinsky I, Laranjeira R, Ramisetty-Mikler S, Caetano R. Violência entre parceiros íntimos e consumo de álcool. Rev Saúde Pública 2010; 44:53-9.

34. Duarte EC, Monteiro RA, Mascarenhas MDM, Silva MMA. As violências e os acidentes como problema de saúde pública no Brasil: marcos das políticas públicas e a evolução da morbimortalidade durante os 20 anos do Sistema Único de Saúde. In: Ministério da Saúde, organizador. Saúde Brasil 2008: 20 anos do Sistema Único de Saúde (SUS) no Brasil. Brasilia: Ministério da Saúde; 2009. p. 311-36.

35. Crenshaw K. Mapping the margins: intersectionality, identity politics, and violence against women of color. Stanford Law Rev 1991; 43:1241-99.

36. Taquete SR. Interseccionalidade de gênero, classe e raça e vulnerabilidade de adolescentes negras às DST/AIDS. Saúde Soc 2010; 19 Suppl 2:51-62.

37. Cunha DB, de Almeida RM, Sichieri R, Pereira RA. Association of dietary patterns with BMI and waist circumference in a low-income neighbourhood in Brazil. Br J Nutr 2010; 104:908-13.

38. Ferreira VA, Magalhães R. Obesidade e pobreza: o aparente paradoxo. Um estudo com mulheres da Favela da Rocinha, Rio de Janeiro, Brasil. Cad Saúde Pública 2005; 21:1792-800.

39. Monteiro CA, Conde WL, Popkin BM. Income-specific trends in obesity in Brazil: 1975-2003. Am J Public Health 2007; 97:1808-12.

40. Gunter J. Intimate partner violence. Obstet Gynecol Clin North Am 2007; 34:367-88.

41. Seematter G, Dirlewanger M, Rey V, Schneiter P, Tappy L. Metabolic effects of mental stress during over- and underfeeding in healthy women. Obes Res 2002; 10:49-55.

42. Seematter G, Guenat E, Schneiter P, Cayeux C, Jequier E, Tappy L. Effects of mental stress on insulin-mediated glucose metabolism and energy expenditure in lean and obese women. Am J Physiol Endocrinol Metab 2000; 279:E799-805.
43. Seywert AJ, Tappy L, Gremion G, Giusti V. Effect of a program of moderate physical activity on mental stress-induced increase in energy expenditure in obese women. Diabetes Metab 2002; 28:178-83.

44. Kivimaki M, Head J, Ferrie JE, Shipley MJ, Brunner E, Vahtera J, et al. Work stress, weight gain and weight loss: evidence for bidirectional effects of job strain on body mass index in the Whitehall II study. Int J Obes (Lond) 2006; 30:982-7.

45. Reichenheim ME, Klein R, Moraes CL. Assessing the physical violence component of the Revised Conflict Tactics Scales when used in heterosexual couples: an item response theory analysis. Cad Saúde Pública 2007; 23:53-62.

46. Koenker R, Bassett G. Regression quantiles. Econometrica 1978; 46:33-50.

47. Barros EG, Pereira RA, Sichieri R, Veiga GV. Variation of BMI and anthropometric indicators of abdominal obesity in Brazilian adolescents from public schools, 2003-2008. Public Health Nutr 2014; 17:345-52

48. Silva RCR, Assis AMO, Szarfarc SC, Pinto EJ, Costa LCC, Rodrigues LC. Iniquidades socioeconômicas na conformação dos padrões alimentares de crianças e adolescentes. Rev Nutr 2012; 25:451-61.

49. World Heaçth Organization. WHO Mutli-country Study on Women's Health and Domestic Violence against Women: Brazil. http://www.who.int/ gender/violence/who_multicountry_study/fact sheets/Brazil2.pdf (accessed on 05/Apr/2012).

50. Jewkes R. Intimate partner violence: causes and prevention. Lancet 2002; 359:1423-9.

51. Roberts AL, McLaughlin KA, Conron KJ, Koenen KC. Adulthood stressors, history of childhood adversity, and risk of perpetration of intimate partner violence. Am J Prev Med 2011; 40:128-38.

Submitted on 10/Nov/2013

Final version resubmitted on 29/May/2014

Approved on 03/Jul/2014 